\title{
The Principle of Open Individuality as a Basis for Teenagers' Creative Interaction with Lyric Poems
}

\author{
Ksenia V. Mironova* \\ Psychological Institute of the Russian Academy of Education, Moscow, Russia \\ *Corresponding author. E-mail: kseniamir@inbox.ru
}

Background. Although lyric poetry contains enormous opportunities for personal development of teenagers, expanding the scope of aesthetic experiences available to them, students often respond to it with hostility, for it is rather hard for them to comprehend. While much prior research has stressed the importance of teaching poetry to adolescents, the psychodidactic foundations of developing their creative interaction with lyric poetry and the role of textbooks in this process remain virtually unexplored.

Objective. To examine the psychodidactic foundations of developing teenagers' creative interaction with lyric poetry: the relevant principles and their implementation in an educational book of a new - psychodidactic - type, which determines the strategy and tactics of the joint study activity modeled in it.

Design. A teaching intervention was conducted, which included whole-class discussions of the poems and work with educational books based on psychodidactic principles. Participants were 311 6th-8th grade students from four Moscow secondary schools.

Results. The principle of open individuality was singled out as the basic one and was elaborated in four interrelated sub-principles: wholeness, polylogy, multidimensionality, and value hierarchy. These principles were implemented in two educational book chapters on lyric poems by A. Pushkin and M. Lermontov. The Wilcoxon signed-rank test conducted upon the results before and after the intervention revealed that the control group showed no significant changes, whereas the final results of the experimental group revealed significant $(p<.001)$ increases in the level of the assessed aspects of creative interaction: description of one's impression, interpretative opinion, lyric plot, experiences of the lyric hero, and figurative language.

Conclusion. Building the learning process on the psychodidactic principles mentioned above, as well as working with educational books based upon these principles, is effective in developing teenagers' creative interaction with lyric poems, turning the reading of poetry into a valuable experience.

\author{
Keywords: \\ creative \\ interaction; \\ psychodidactic \\ principles; \\ open \\ individuality; \\ lyric poetry; \\ teenagers
}




\section{Introduction}

Reading lyric poetry is often considered as something related mostly to literature and aesthetics, but actually it should be viewed more holistically, as part of how individuals perceive, understand, and value themselves, other people, and reality at large. Poetry comprehension and appreciation are inextricably linked with exploring the inner and outer worlds, one's values, thoughts, feelings, and emotions (e.g., Dias \& Hayhoe, 1988; Eva-Wood, 2004; Leontiev, 2010; Novlyanskaya \& Kudina, 2014; Peskin, 2010; Rosenblatt, 2004). Vygotsky called art, including lyric poetry, "a method for finding an equilibrium between man and the world, in the most critical and important stages of his life" (Vygotsky, 1986, p. 329). Researchers generally agree that adolescence is one of these stages. Modern teenagers are in dire need of such balancing, gaining control over their feelings, as they are exposed to various external and internal struggles connected with growth issues, self-esteem, trust and acceptance, peer pressure, etc. (Fel'dshtein, 2004; Rice \& Dolgin, 2005; Tolstykh \& Prikhozhan, 2016). Lyric poetry contains enormous opportunities for personal development of adolescents, expanding the scope of aesthetic experiences available to them, promoting a thoughtful attitude towards oneself and others.

All too often, however, teenagers lose interest in poetry during secondary school and gradually start responding to it with hostility (e.g., Andrews, 1991; Dymoke, Barrs, Lambirth, \& Wilson, 2015; Fleming 1992; Gutkina, 2015). The difficulties students have in making sense of the poems, constructing both the literal and figurative meaning of the text, may not only diminish their appreciation of the poems, but even lead to frustration (Hanratty, 2011; Mathieson, 1980; Peskin, 1998). Frustration may also occur when the reader adopts the wrong reading stance, by approaching poems to gain information as one might approach a reference book, or by giving prose translations of the poem's literal meanings instead of exploring the symbolic content (Dias \& Hayhoe, 1988; Eva-Wood, 2004; Fleming, 1992; Harker, 1994; Peskin, 2010; Rosenblatt, 1980). Another problem is secondary school teachers' lack of confidence with poetry due to the difficulties they experience teaching it and attempting to maintain students' interest in it, as well as assessing the students' comprehension of a poem (Benton, 1984; Wade \& Siddaway, 1990; Xerri, 2016). Therefore, there is a tendency to unofficially squeeze poetry out of the curriculum on the grounds that it is irrelevant and largely incomprehensible for the teenagers. As a result, poetry's potential remains unfulfilled, and there is often a gap between the stated objectives and actual learning experiences.

Although much prior research has stressed the importance of teaching poetry to adolescents, the psychodidactic foundations of developing their creative interaction with lyric poetry and the role of textbooks in this process remain virtually unexplored. This brings us to the aims of our work, which were to investigate these foundations: to reveal the relevant psychodidactic principles and implement them in an educational book of a new - psychodidactic - type, which determines the strategy and tactics of the joint study activity modeled in it (Granik, 2009; Granik \& Borisenko (Eds.), 2018; Soboleva, 2019). These books contain a kind of scenario for the learning process, constructed with consideration of the patterns and mechanisms of students' mental development. In some cases, the text of the psychodidactic educational book is similar to the teacher's narrative, a mini-lecture, but more 
often it is like a conversation with the young reader. Particular attention is paid to promoting students' cognitive interest and providing feedback - possible answers and thoughts regarding some of the questions raised.

Psychodidactics is the area of educational psychology that integrates psychological, didactic, methodological, and subject knowledge, while shifting the emphasis to students' personal development (e.g., Davydov, 1996; Gelfman \& Kholodnaya, 2006; Panov, 2007). According to the psychodidactic approach, the assimilation of knowledge, the formation of skills and abilities, are viewed not as learning objectives, which is characteristic of the didactic approach, but as a means of developing the student's cognitive and personal spheres (Kholodnaya \& Gelfman, 2016; Panov, 2007; Stones, 1978). The practical implementation of the psychodidactic principles in educational books will make it possible to overcome the existing gap between scientific research and pedagogical practice.

\section{The Psychodidactic Principle of Open Individuality}

We consider the comprehension of lyric poetry as a purposeful process of creative interaction of the reader with the poem, which process comprises three consecutive stages: 1) the syncretic - a holistic grasp of meaning, indivisible unity of feelings, thoughts, and emotions during the first reading of the poem; 2 ) the analytic analysis of the lyric plot, figurative language, poetic form and structure; and 3) the synthetic - interpretative synthesis based on emotional and cognitive processes (Mironova, 2018). We agree with the point of view shared by many researchers that the reader's experiencing of the text and the reader's search for meaning contained in the text are equally important for comprehension of poetry (e.g., Belyaeva, 2004; Eva-Wood, 2004; Fleming, 1996; Fleming \& Stevens, 2015; Hanratty, 2011; Sigvardsson, 2017). For the purpose of measurement, we operationalized the theoretical construct by specifying the main indicators of creative interaction with a poem: at the first stage, description of one's impression (feelings, thoughts, emotions); at the second stage, description of the lyric plot and the experiences of the lyric hero, recognition of figurative language and description of its role in the poem; at the third stage, interpretation of the poem, substantiation of one's opinion.

As a result of the analysis, generalization, and systematization of knowledge about the research problem, we identified the principle of open individuality as the basis for creative interaction of teenagers with lyric poetry. This implies, firstly, meaningful communication with the poem regarded as an aesthetic individuality, a soul opened to the reader; and secondly, the reader's self-discovery and selfdisclosure, awakened, inspired, and intensified by the poem, which presupposes personal and interpersonal reflection. This principle is the basic one, since in order for deep interaction with the lyric poem to take place, it is necessary to realize that poetry is a condensed form of self-expression, and therefore the reader's openness is required - openness to the poem, i.e., willingness to respond to it emotionally and intellectually; as well as openness to oneself, i.e., readiness for self-exploration, reflection, enrichment of one's experience. Openness does not mean vulnerability or dissolving oneself in someone else's mind; as Bakhtin noted, the reader should capture and apply a dual vision from both within and without (Bakhtin, 1986). The 
process of creative interaction with a poem presupposes the meeting of open individuals - the author and the reader.

The general principle of open individuality can be elaborated in four sub-principles: wholeness, polylogy, multidimensionality, and value hierarchy.

The principle of wholeness means, firstly, applying a holistic approach to a person (to oneself and other people, including the poet and the lyric hero), who is viewed as an integral individual with a unique inner world irreducible to its separate characteristics; secondly, considering the lyric poem as a wholeness, which predetermines our understanding of the parts and ensures their unity, and as an expression of a part of mental life, which, when placed by the poet at the center of attention, acquires the properties of the whole, i.e., of a complete, full-fledged artwork. Practical implementation of this principle requires repeated meaningful reading of the poem, including a return to consideration of it as a whole after talking about any of its semantic aspects (parts). It also means exploring, through the experiences expressed in the poem, the unique features of the lyric hero's inner world, his or her mental life and perception of the external world. It is important to emphasize that during this process of exploration, students build a meta-awareness of not only what they are doing, but why and how.

The principle of polylogy (from the Greek words poly, "many", and logos, "word" or "discourse") implies a meaning-opening and meaning-making subject-to-subject interaction, which involves the alternation and co-presence of various voices: that of the poet, the critics, the teacher, the students (classmates) - all of whom are given equal space and weight and are unified by a joint search for truth, for explicit and implicit meanings. Improving the effectiveness of communication is crucial when working with adolescents, for whom communication comes to the forefront of learning, turns into the leading activity that becomes a subjective means of their personal, cognitive, social development (El'konin, 1971). Therefore, researchers stress the importance of vivid discussions during poetry lessons, especially with teenage students (Dymoke et al., 2015; Fleming \& Stevens, 2015; Hanratty, 2011; Vala, Sladová, Řeřichová, \& Fic, 2014). Schoolchildren often get used to the idea that each artwork has a certain standard interpretation needed to be uncritically accepted and memorized. The principle of polylogy takes into account the plurality of meaning, i.e., the possibility of different readings of a text, provided they are wellsupported by textual evidence, and respecting another person's opinion, which may be used as a springboard for one's own analysis.

The principle of multidimensionality means, firstly, regarding the lyric poem as a multi-level structure containing different semantic layers that are closely soldered to each other and at the same time have a certain independence from each other; secondly, expanding the intellectual experience of a teenager in the process of revealing the connections of the poem with the legacy of the world's philosophical and psychological wisdom. In order to discover various semantic dimensions, it is important to activate students' attention to all text elements, to encourage them to delve into the poem's lines, stanzas, and figurative language. Detail-oriented reading heightens the reader's sensitivity to the nuances used to convey a particular state or mood. Putting the poetic text into a wider context and exploring the symbolism of the poem activate adolescents' imagination, and their intellectual and emotional spheres. 
The principle of value hierarchy presupposes, firstly, identifying the axiological foundations that underlie the poem, including the universal values (e.g., peace, love, freedom) and the subjective, relative ones, related to the personally significant attitude of the lyric hero toward the described internal event (situation). Secondly, the principle presupposes alignment of intra-value gradation, i.e., possible levels of manifestation of a particular value expressed in the poem. Key ways of implementing this principle include polarization of values for a clearer awareness of the value content: formulating axiological poles - the one from which the lyric hero emanates and its opposite; and referring to the personal experience of the student, considering the poem in the context of personal and general cultural meanings.

These principles are closely interconnected, interdependent. To bridge the gap between theory and practice, we implemented these principles while writing educational books - two chapters devoted to lyric poems by the renowned Russian poets A. Pushkin and M. Lermontov (Mironova, 2012, 2019). The next step of our research was the experimental validation of the principles and chapters, to discover whether there is a positive trend in the development of the teenagers' ability to creatively interact with the poems as a result of building the learning process on psychodidactic principles and working with educational books of the psychodidactic type.

\section{Method}

\section{Participants}

The sample consisted of 311 students in 6th $(\mathrm{n}=102), 7$ th $(\mathrm{n}=115)$, and 8 th $(\mathrm{n}=94)$ grades from four Moscow secondary schools; age $M=13.7, S D=0.88$, age range 11.9-15.3. They were divided into experimental $(n=236)$ and control $(n=75)$ groups.

\section{Materials}

As stimulus material, we used five poems by A. Pushkin ("Winter Morning",

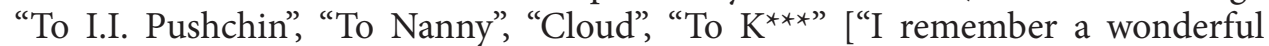
moment ..."]) and five poems by M. Lermontov ("The Rock", "In the Wild North Stands Lonely..., "When Yellowish Fields Get Ruffled..., "Clouds", "The Sail”). The experimental group worked with two educational book (EdB) chapters - "Conversations about A.S. Pushkin's lyrics" (Mironova, 2019) and "Eleven poetic masterpieces" (Mironova, 2012).

\section{Procedure and Measures}

Work with the experimental (E) group included whole-class discussions of the poems based on the EdB chapters, individual and whole-class chapter reading, and working with the $\mathrm{EdB}$ chapters. The intervention took place during regular literature lessons and was conducted for one and a half months. There were one or two lessons per week for a total of eight lessons per class. The control (C) group studied as usual, using traditional textbooks. 
Before and after the teaching intervention, all participants completed openended writing tasks, in which they had to describe in detail: (a) their impression of the poem - their feelings, thoughts, emotions, (b) the lyric plot, (c) the experiences of the lyric hero, (d) the main literary devices used in the poem and their role in it, and (e) the meaning that, in their opinion, the poet wanted to convey. Students were required to use textual evidence to support their reasoning. These tasks correspond to the main indicators of creative interaction with a poem mentioned earlier.

Based on the assessment criteria, we conducted a qualitative analysis of the written responses. Impression description was coded as " 1 " if it was limited to com-

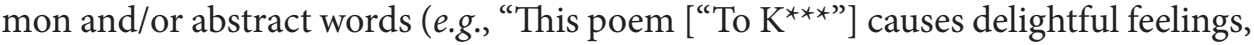
solemn thoughts of love and inspiration"), and as "2" if it was more specific, personal ("The poem "To I.I. Pushchin" makes me feel like I'm parting with my best friend. I admire the way Pushkin and Pushchin fearlessly supported each other. I think in the past people used to know how to be friends more, really valued friendship"). To assess lyric plot description, experts (philologists) singled out key elements of explicit-implicit content (KEEIC) for each poem. Scoring for these assignments was based on the number of KEEIC that students mentioned in their responses: "1"- less than a half; "2" - one half or more than a half; " 3 " - all the KEEIC. Description of the experiences of the lyric hero was coded as " 1 " if it was brief, incomplete, and as " 2 " if it was detailed and well-reasoned. Figurative language recognition and description of its role in the poem was coded as "1" if at least one literary device (an example of figurative language) was identified, but the role it plays in the poem was not explained; as "2" if 1-2 literary devices were identified and their role was explained; as " 3 " if 3 or more literary devices were identified and their role was explained.

The results of the final task - interpretation of the poem, substantiation of one's opinion - were coded as follows: " 1 " - partially correct but containing a distortion of meaning; "2" - correct but not reasoned well enough; " 3 " - well-reasoned, text-based. It needs to be clarified what is meant in this case by "correct". Without diminishing the importance of the subjective response, we consider it necessary to recognize that poetry also has an objective semantic layer, the understanding of which must remain invariant with respect to individual perception. Partially or completely incorrect interpretation of this layer is an indicator of insufficient reading competence. That is why participants were asked to use text-based examples to defend their interpretations of the poem's deeper meanings.

The differences between the groups were compared using the Kruskal-Wallis test, and the differences within the groups before and after the experimental validation, using the Wilcoxon signed-rank test. The pairwise differences were evaluated using the Mann-Whitney test.

\section{Results}

Prior to the teaching intervention, the Mann-Whitney test showed no significant differences $(p>0.05)$ between the results of the experimental and control groups. The same test conducted upon the final results after intervention revealed statistically significant differences $(p<.001)$. The E-group as a whole showed higher results in each of the assessed aspects of creative interaction with poetry. 
The Kruskal-Wallis analysis of variance revealed that initially, 8th-graders outperformed 6th- and 7th-graders statistically significantly in most of the tasks, except for impression description (see Table 1). After intervention, their results were still higher in assignments concerning figurative language and poem interpretation.

Table 1

Results of the Kruskal-Wallis test before and after the intervention (E-group)

\begin{tabular}{|c|c|c|c|c|c|}
\hline Indicators & $\begin{array}{l}\text { Impres- } \\
\text { sion } \\
\text { descrip- } \\
\text { tion }\end{array}$ & $\begin{array}{l}\text { Lyric } \\
\text { plot } \\
\text { descrip- } \\
\text { tion }\end{array}$ & $\begin{array}{l}\text { Descrip- } \\
\text { tion of the } \\
\text { experiences } \\
\text { of the lyric } \\
\text { hero }\end{array}$ & $\begin{array}{l}\text { Figurative } \\
\text { language } \\
\text { recognition and } \\
\text { description } \\
\text { of its role }\end{array}$ & $\begin{array}{l}\text { Interpretation } \\
\text { of the poem, } \\
\text { substantiation } \\
\text { of one's } \\
\text { opinion }\end{array}$ \\
\hline \multicolumn{6}{|l|}{ Before } \\
\hline Grade 6 mean rank & 125.39 & 120.16 & 119.34 & 94.66 & 118.28 \\
\hline Grade 7 mean rank & 107.88 & 98.48 & 107.83 & 114.50 & 99.70 \\
\hline Grade 8 mean rank & 123.70 & 140.89 & 130.50 & 149.87 & 141.51 \\
\hline$x^{2}$ & 4.781 & 19.297 & 6.335 & 31.837 & 17.523 \\
\hline$d f$ & 2 & 2 & 2 & 2 & 2 \\
\hline $\mathrm{p}$ & .092 & .000 & .042 & .000 & .000 \\
\hline \multicolumn{6}{|l|}{ After } \\
\hline Grade 6 mean rank & 108.53 & 120.37 & 124.47 & 99.20 & 116.87 \\
\hline Grade 7 mean rank & 126.40 & 109.35 & 110.67 & 109.94 & 107.02 \\
\hline Grade 8 mean rank & 120.02 & 127.50 & 121.35 & 150.35 & 134.22 \\
\hline$x^{2}$ & 3.688 & 3.476 & 2.520 & 28.225 & 7.728 \\
\hline$d f$ & 2 & 2 & 2 & 2 & 2 \\
\hline $\mathrm{p}$ & .158 & .176 & .284 & .000 & .021 \\
\hline
\end{tabular}

Although 8th-graders outperformed the other students before the intervention, qualitative analysis revealed that they have serious poetry comprehension problems as well. Thus, $46.8 \%$ of their written responses contained a distortion of the poem's meaning, and only $2.1 \%$ of the 8 th-graders were able to give a wellreasoned, text-based interpretation. After the intervention, the former number in these classes decreased to $14.9 \%$, while the latter increased to $34.0 \%$.

The Wilcoxon signed-rank test conducted upon the results of the groups before and after the intervention revealed that the E-group showed significant $(p<.001)$ increases in the level of the assessed aspects of creative interaction with a poem, whereas in the C-group there were no significant changes (see Table 2).

In the beginning, only $13.1 \%$ of the E-group students expressed feelings and thoughts directly related to the text and were able to put the poem in the context of their life experience. In the end, this number rose to $51.3 \%$. 
Table 2

Results of the Wilcoxon signed-rank test

\begin{tabular}{|c|c|c|c|c|c|c|c|}
\hline \multicolumn{3}{|c|}{ Indicators } & \multirow{2}{*}{$\begin{array}{l}\begin{array}{c}\text { Impres- } \\
\text { sion } \\
\text { descrip- } \\
\text { tion }\end{array} \\
-5.000^{*}\end{array}$} & \multirow{2}{*}{$\begin{array}{c}\begin{array}{c}\text { Lyric } \\
\text { plot } \\
\text { descrip- } \\
\text { tion }\end{array} \\
-7.553^{\star}\end{array}$} & \multirow{2}{*}{$\begin{array}{c}\begin{array}{c}\text { Description } \\
\text { of the experi- } \\
\text { ences of the } \\
\text { lyric hero }\end{array} \\
-6.677^{\star}\end{array}$} & \multirow{2}{*}{$\begin{array}{c}\begin{array}{c}\text { Figurative } \\
\text { language rec- } \\
\text { ognition and } \\
\text { description } \\
\text { of its role }\end{array} \\
-7.374^{*}\end{array}$} & \multirow{2}{*}{$\begin{array}{c}\begin{array}{c}\text { Interpretation } \\
\text { of the poem, } \\
\text { substantiation } \\
\text { of one's } \\
\text { opinion }\end{array} \\
-7.437^{\star}\end{array}$} \\
\hline E-group & $\mathrm{Z}$ & Grade 6 & & & & & \\
\hline & & Grade 7 & $-6.824^{\star}$ & $-7.924^{\star}$ & $-6.553^{\star}$ & $-7.469^{\star}$ & $-8.008^{\star}$ \\
\hline & & Grade 8 & $-5.533^{\star}$ & $-7.244^{\star}$ & $-5.466^{\star}$ & $-6.818^{\star}$ & $-7.133^{\star}$ \\
\hline \multirow[t]{3}{*}{ C-group } & $\mathrm{Z}$ & Grade 6 & -.302 & -.500 & .000 & .000 & -2.77 \\
\hline & & Grade 7 & -.333 & -.302 & -.707 & .000 & .000 \\
\hline & & Grade 8 & -.707 & -.333 & -.378 & -.816 & -.577 \\
\hline
\end{tabular}

Note. ${ }^{*} p<0.001$

As illustrated in Figure 1, after the intervention the E-group participants performed much better in tasks on lyric plot description. For instance, the number of adolescents who pointed out all the key elements of the explicit and implicit content significantly increased. The highest results (42.3\%) were obtained in Grade 8 (E-8); however, in general, the differences in the E-group between the results of the students in 6 th, 7 th, and 8 th grades were insignificant.

\section{Group means}

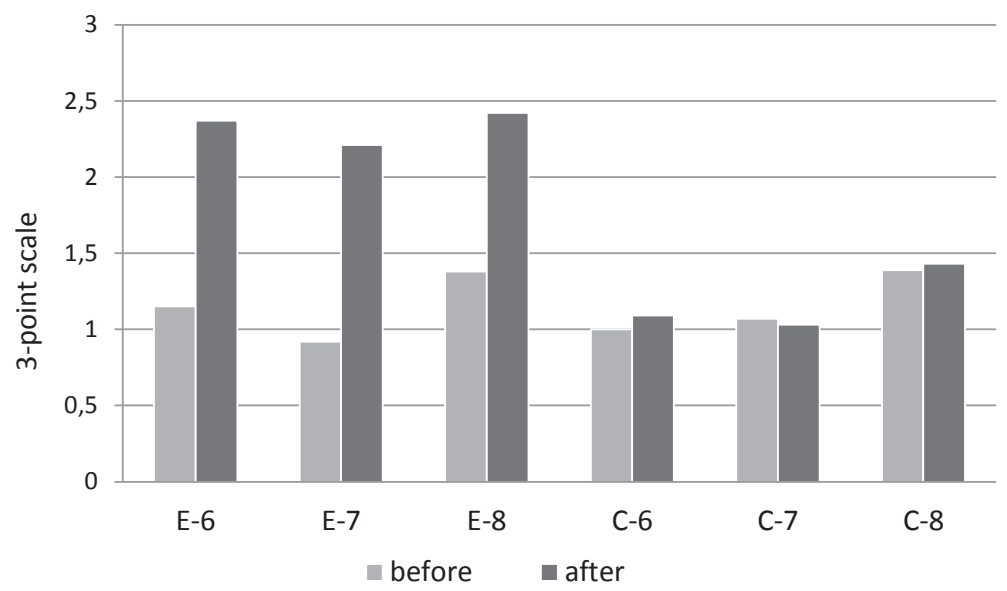

Figure 1. Lyric plot description: group dynamics

Note: $\mathrm{E}=$ experimental group, $\mathrm{C}=$ control group, $6=6$ th-graders; $7=7$ th-graders; $8=8$ th-graders .

One of the key problems was the "loss" of the lyric hero. Most of the participants tried to identify an external event line and did not trace the development of the inner state of the hero, did not discuss the psychological situation described in the poem. While prior to intervention, the descriptions of the experiences of the 
hero were often reduced to a few common words, after it the number of detailed, substantiated answers increased from $15.7 \%$ to $59.3 \%$.

Eighth-graders generally performed better in figurative language tasks. After the intervention, the number of students who identified 1-2 literary devices and explained their role in the poem increased from $23.9 \%$ to $50.7 \%$. Of the 8 th-graders, $29.6 \%$ were able to identify and explain three or more literary devices. As for the 6 th- and 7 th-graders, only $1.3 \%$ and $3.5 \%$, respectively, identified three or more devices, but, like the 8 th-graders, about $50 \%$ of the students coped with 1-2 literary devices.

Before the intervention, the percentage of students in the E-group who gave no interpretation of the poem or gave a completely wrong interpretation was quite high (31.4\%), and nearly half of the answers contained a distortion of the poem's meaning. As the qualitative analysis of the written responses showed, the teenagers often perceived a poem not holistically but fragmentarily; losing sight of the general context, they misinterpreted the meanings of the figurative expressions. The overall number of participants who were able to reasonably interpret a poem and justify their opinion was minimal: less than $1 \%$. After the intervention, this number increased to $31.4 \%$. Thus, the written responses on "To I.I. Pushchin", for example, reflected how the work with the EdB chapters and detailed discussions based on psychodidactic principles helped the students to engage with the poem on a more personal level and sharpen their critical skills. One 7th-grader, for instance, wrote, "Actually, I already knew this poem by heart, but it never occurred to me that in the second part the lyric hero is talking not about his own exile, but his friend's imprisonment. I now see that this poem is not merely about true friendship, it's also about hope and freedom. I mean not just outer freedom, but, more importantly, inner freedom, which cannot be taken away from you unless you betray yourself and what you believe $i n$ ". These insightful comments show that the student was able to look at the poem from a different angle, to respond to its broader significance.

\section{Discussion}

Among modern teenagers, there is often a hostile attitude to lyric poetry, as they fail to find meaning in it, to see any connection between it and their lives. In Russian secondary schools, poetry is usually taught in a limited and restrictive way, the typical form of studying poems being learning them and their most widespread interpretations by heart. This means that there is seldom any discussion, and the students remain emotionally and intellectually passive and view poetry reading as an exercise in futility. Therefore, researchers talk about poor progress in poetry comprehension throughout early adolescence, which can be explained by the lack of attention paid during literature lessons to lyric poetry and by the lack of effectiveness in developing creative interaction with poems. Other reasons for teenagers' low level of understanding of both fictional and factual texts may include shortcomings in the quality of textbooks and their use in the educational process (Granik \& Borisenko (Eds.), 2018; Zuckerman, Kovaleva, \& Kuznecova, 2011). In this situation, it becomes obvious that the traditional didactic teacher-centered and knowledge-oriented approach is not effective enough, especially when it comes to poetry, which deals primarily with exploring a person's inner world - thoughts, 
feelings, and emotions. Creative interaction with a poetic text presupposes going beyond the surface information to the deep level of meaning, both cognitive and emotive.

In order to investigate the theoretical and practical aspects of developing adolescents' creative interaction with lyric poems, we applied the psychodidactic approach. In the course of our research, the principle of open individuality was singled out as the basic one and was elaborated in four interrelated sub-principles: wholeness, polylogy, multidimensionality, and value hierarchy. We implemented these principles in two educational book chapters devoted to several lyric poems by A. Pushkin and M. Lermontov.

At the beginning of the experimental validation of the principles and chapters, the students who participated in our study completed open-ended writing tasks, in which they had to describe their impression of the poem, the lyric plot, the figurative language, and the experiences of the lyric hero, and to give a justified interpretation of the poem's overall meaning. For many of the participants, these tasks seemed quite daunting, because it was the first time they had to think about a poem, to try to respond to it. Since lyric plots are typically based on an internal event and involve psychological phenomena, when the students tried to focus on gaining some sort of information from the poem, they were unable to see the dimensions of the situation (or perception, attitude, recollection, emotion, etc.) depicted in it.

During the teaching intervention, our aim was not so much to uncover the socalled objective meaning of the text, as to help the students interact with the poem and with each other at a deeper level, and to link the work of art with their own experience. The teachers who observed the experimental lessons were surprised by the teenagers' willingness to engage enthusiastically in the joint activities. Due to the students' active participation, their confusion dissipated, and it became obvious that most of them started to enjoy the process of interpreting a poem, sharing their personal views on it, working with the educational book chapters and discussing them.

The final results of the experimental group showed significant $(p<0.001)$ increases in the level of the assessed aspects of creative interaction. While before the intervention a "fractional" (fragmentary) approach to the poem prevailed, when the text seems disjointed, after the intervention there appeared a tendency to apply a holistic approach, when the reader is able to trace the development of the inner state of the hero, to navigate the text, establishing the relationships between its elements and seeing their correlation with the whole, and to choose contextually relevant meanings in words. It was clear that not all students who freely expressed themselves during oral discussions were able to fully convey their emotions and ideas in written form. Nevertheless, the final written responses showed that most of the active participants began to grasp deeper meanings embedded in the text, and their perception became more detailed and concrete as they tried to look at the poem from various perspectives.

Thus, we revealed positive dynamics in the development of teenagers' creative interaction with the lyric poems as a result of the teaching intervention. The findings suggest that building the learning process on the general principle of open individuality and the sub-principles of wholeness, polylogy, multidimensionality, 
and value hierarchy, as well as working with educational books of the psychodidactic type based upon these principles, is effective in deepening teenagers' comprehension of poetry, fostering dialogical exchange, turning the reading of lyric poetry into a valuable experience for teenagers during their years of growth and self-exploration.

\section{Limitations}

The limitations of the study are related to the fact that due to the school curriculum (full schedule), we were able to conduct only a short-term intervention and therefore did not investigate how far the positive changes we found were spread, how stable they were, whether there would be a transfer effect when reading and analyzing other lyric poems. Additionally, although students from the experimental group showed statistically significant gains, overall these gains were relatively small. We assume that more time spent implementing the teaching intervention might increase the benefits. The limitations mentioned above are prerequisites for further special studies. Future research might also incorporate other age groups, e.g., high school students.

\section{Acknowledgements}

We thank all the students and school administrators who allowed us to conduct the empirical study.

\section{References}

Andrews, R. (1991). The problem with poetry. Milton Keynes, UK: Open University Press.

Bakhtin, M.M. (1986). Estetika slovesnogo tvorchestva [Aesthetics of verbal creativity]. Moscow: Iskusstvo.

Belyayeva, N.V. (2004). Uroki izucheniya liriki $v$ shkole. Teoriya i praktika differentsirovannogo podkhoda $k$ uchashchimsya [Learning lyrics at school. Theory and practice of a differentiated approach to students]. Moscow: Verbum-M.

Benton, P. (1984). Teaching poetry: The rhetoric and the reality. Oxford Review of Education, 10(3), 319-327. https://doi.org/10.1080/0305498840100310

Davydov, V.V. (1996). Teoriya razvivayushchego obucheniya [Theory of developmental education]. Moscow: Intor.

Dias, P., \& Hayhoe, M. (1988). Developing response to poetry. Milton Keynes; Philadelphia: Open University Press.

Dymoke, S., Barrs, M., Lambirth, A., \& Wilson, A. (Eds.) (2015). Making poetry happen: Transforming the poetry classroom. London: Bloomsbury.

El'konin, D.B. (1971). K probleme periodizatsii psikhicheskogo razvitiya v detskom vozraste [On the problem of periodization of mental development in children]. Voprosy psikhologii [Questions of psychology], 4, 6-20.

Eva-Wood, A.L. (2004). Thinking and feeling poetry: Exploring meanings aloud. Journal of Educational Psychology, 96(1), 182-191. https://doi.org/10.1037/0022-0663.96.1.182

Fel'dstein, D.I. (2004). Psikhologiya vzrosleniya: strukturno-soderzhatel'nyye kharakteristiki protsessa razvitiya lichnosti [Psychology of growing up: structural and substantial characteristics of the process of personality development]. Moscow: Flinta.

Fleming, M. (1992). Pupils' perceptions of the nature of poetry. Cambridge Journal of Education, 22(1), 31-41. https://doi.org/10.1080/0305764920220104 
Fleming, M., \& Stevens, D. (2015). English teaching in the secondary school: Linking theory and practice (pp. 177-195). (4th ed.). Abingdon; NY: Routledge. https://doi.org/10.4324/9781315695006

Gelfman, E.G., \& Kholodnaya, M.A. (2006). Psikhodidaktika shkol'nogo uchebnika: Intellektual'noe vospitanie shkolnikov [Psychodidactics of school textbooks: The intellectual nurture of students]. St. Petersburg: Piter.

Granik, G.G. (2009). Psikhologo-didakticheskiye problemy sozdaniya shkol'nykh uchebnikov [Psychological and didactic problems of creating school textbooks]. Voprosy psykhologii [Questions of psychology], 3, 37-44.

Granik, G.G. \& Borisenko, N.A. (Eds.) (2018). Kak uchit' russkomu yazyku i literature sovremennyh shkol'nikov? Shkol'nyj uchebnik segodnya [How can we teach modern schoolchildren Russian language and literature? The school textbook today]. Moscow, St. Petersburg: Nestor-Istoriya.

Gutkina, E.I. (2015). Lirika i chitatel'-podrostok [Lyrics and the teenage reader]. Biblioteka $v$ shkole [The school library], 4, 37-43.

Hanratty, B. (2011). Poetry and gender: A comparative evaluation of boys' and girls' responses to poetry at Key Stage 4 in Northern Ireland. Research Papers in Education, 26(4), 413-426. http://dx.doi.org/10.1080/02671522.2010.483525

Harker, W.J. (1994). "Plain sense" and "poetic significance": Tenth-grade readers reading two poems. Poetics, 22(3), 199-218. https://doi.org/10.1016/0304-422X(94)90005-1

Kholodnaya, M.A., \& Gelfman, E.G. (2016). Development-focused educational texts as a basis for learners' intellectual development in studying mathematics (DET technology). Psychology in Russia: State of the Art, 9(3), 24-37. http://dx.doi.org/10.11621/pir.2016.0302

Leontiev, D.A. (2010). Poeticheskoye tvorchestvo: ot literaturnogo i kul'turnogo konteksta k zhiznennomu [Poetic creativity: from the literary and cultural context to that of real life]. Bibliotechnoye delo [Librarianship], 10, 20-25.

Mathieson, M. (1980). The problem of poetry. Use of English, 31(2), 36-43.

Mironova, K.V. (2019). Besedy o lirike A.S. Pushkina [Conversations about A.S. Pushkin's lyrics]. In G.G. Granik, L.A. Kontsevaya, K.V. Mironova, A.S. Pushkin, yego druz'ya i sovremenniki: Uchebnoye posobiye po literature dlya uchashchikhsya 7-9 klassov obshcheobrazovatel'nykh organizatsiy [A.S. Pushkin, his friends and contemporaries: A textbook on literature for students in grades 7-9] (pp. 192-264). Moscow: Mnemozina.

Mironova, K.V. (2012). Odinnadtsat' poeticheskikh shedevrov [Eleven poetic masterpieces]. In G.G. Granik \& L.A. Kontsevaya (Eds.), Ya - drugoy. M. Yu. Lermontov: Uchebnaya kniga po russkoy filologii [I'm another. M.Yu. Lermontov: Educational book on Russian philology] (pp. 166-215). Moscow: Ileksa.

Mironova, K.V. (2018). Otsenivaniye urovnya ponimaniya podrostkami liricheskoy poezii [Evaluation of the level of adolescents' lyric poetry comprehension]. In A.L. Zhuravlev, E.A. Sergienko, N.E. Kharlamenkova (Eds.), Psikhologicheskiye issledovaniya: Vyp. 9 [Psychological Studies: Vol. 9] (pp. 87-98). Moscow: Izd-vo "Institut psikhologii RAN".

Novlyanskaya, Z.N., \& Kudina, G.N. (2014). K voprosu o kul'ture chteniya liriki [On the question of the culture of reading lyrics]. In N.L. Karpova (Ed.), Bibliopsikhologiya. Bibliopedagogika. Biblioterapiya [Bibliopsychology. Bibliopedagogics. Bibliotherapy] (pp. 71-75). Moscow: Russkaya shkol'naya bibliotechnaya assotsiatsiya.

Panov, V. I. (2007). Psikhodidaktika obrazovatel'nyh sistem: Teoriya i praktika [Psychodidactics of educational systems: Theory and practice]. St. Petersburg: Piter.

Peskin, J. (1998). Constructing meaning when reading poetry: An expert-novice study. Cognition and Instruction, 16(3), 235-263. http://dx.doi.org/10.1207/s1532690xci1603_1

Peskin, J. (2010). The development of poetic literacy during the school years. Discourse Processes, 47(2), 77-103. http://dx.doi.org/10.1080/01638530902959653

Rice, F.P., \& Dolgin, K.G. (2005). The adolescent: Development, relationships and culture (11th ed.). Auckland, New Zealand: Pearson Education New Zealand.

Rosenblatt, L.M. (1994). The reader, the text, the poem: The transactional theory of the literary work. Carbondale, IL: Southern Illinois Press.

Rosenblatt, L.M. (1980). "What facts does this poem teach you?" Language Arts, 57(4), 386-394. Retrieved from http://www.jstor.org/stable/41404974 
Sigvardsson, A. (2017). Teaching poetry reading in secondary education: Findings from a systematic literature review. Scandinavian Journal of Educational Research, 61(5), 584-599. https://doi.org/10.1080/00313831.2016.1172503

Soboleva, O.V. (2019). Psikhodidakticheskiye osnovy obucheniya ponimaniyu teksta: ot teorii k praktike postroyeniya uchebnoy knigi [Psychodidactic bases of teaching text comprehension: from theory to practice of constructing an educational book]. In N.A. Borisenko (Ed.), Psikhodidaktika sovremennogo uchebnika: preemstvennost' tradicij i vektory razvitiya [Psychodidactics of the modern textbook: continuity of traditions and development vectors] (pp. 44-49). Moscow: Mnemozina.

Stones, E. (1978). Psychopedagogy: Theory and practice in teaching. British Educational Research Journal, 4(2), 1-19. https://doi.org/10.1080/0141192780040201

Tolstykh, N.N., \& Prikhozhan, A.M. (2016). Psikhologiya podrostkovogo vozrasta [Psychology of adolescence]. Moscow: Yurayt.

Vala, J., Sladová, J., Rerrichová, V., \& Fic, I. (2014). The changes in the attitudes towards poetry in the class (14-15 years old) thanks to experimental teaching methods. Procedia - Social and Behavioral Sciences, 116, 3811-3815. Retrieved from https://www.sciencedirect.com/science/article/pii/S1877042814008635

Vygotsky, L.S. (1986). Psikhologiya iskusstva [The psychology of art]. Moscow: Iskusstvo.

Wade, B., \& Sidaway, S. (1990). Poetry in the curriculum: A crisis of confidence. Educational Studies, 16(1), 75-83. https://doi.org/10.1080/0305569900160106

Xerri, D. (2016). 'Poems look like a mathematical equation': Assessment in poetry education. International Journal of English Studies, 16(1), 1-17. https://doi.org/10.6018/ijes/2016/1/235261

Zuckerman, G.A., Kovaleva, G.S., \& Kuznecova, M.I. (2011). Pobeda v PIRLS i porazhenie v PISA: sud'ba chitatel'skoy gramotnosti 10-15-letnikh shkol'nikov [Victory in PIRLS and defeat in PISA: the future of reading literacy of 10-15-year-olds]. Voprosy obrazovaniya [Educational studies], 2, 123-150. https://doi.org/10.17323/1814-9545-2011-2-123-150

Original manuscript received July 31, 2019

Revised manuscript accepted October 25, 2019

First published online December 25, 2019

To cite this article: Mironova, K. (2019). The Principle of Open Individuality as a Basis for Teenagers' Creative Interaction with Lyric Poems. Psychology in Russia: State of the Art, 12(4), 135-147. DOI: 10.11621/pir.2019.0408 